\title{
Garden ponds as potential introduction pathway of ornamental crayfish
}

\author{
J. Patoka(1),^, M. Petrtýl(1), L. Kalous ${ }^{(1)}$ \\ Received February 10, 2014 \\ Revised April 16, 2014 \\ Accepted April 16, 2014
}

Key-words:

alien species, introduction

pathway, ornamental animal, pond, release

\section{ABSTRACT}

The private stocking of ornamental crayfish in garden ponds was discussed in previous studies, but there is a lack of detailed analysis for better understanding of this introduction pathway. The Czech Republic is one of leading EU countries in trade with ornamental crayfish and private garden ponds are popular among people. The crayfish keepers in the country were interviewed by self-administered questionnaire to gather data about principal characteristics of the keepers and detailed information about crayfish breeding that are of interest for conservation managers. Besides of releasing crayfish into garden ponds, alarming illegal behavior such as releasing of juvenile crayfish into the wild, and capturing of indigenous crayfish from wild populations, were registered. Therefore focusing on public education to increase awareness of possible unwanted consequences of crayfish release and introduction of an obligation to inform customers about hazardousness of non-indigenous crayfish species for retailers and wholesalers is recommended.

\section{RÉSUMÉ}

\section{Les bassins de jardin comme voie potentielle d'introduction d'écrevisses ornementales}

Mots-clés : espèces exotiques, voie d'introduction, animal d'ornement, étang, relâcher
Le stockage privé d'écrevisses ornementales dans les bassins de jardin a été discuté dans des études précédentes, mais il y a un manque d'analyse détaillée pour une meilleure compréhension de cette voie d'introduction. La République tchèque est l'un des principaux pays de l'UE pour les échanges d'écrevisses d'ornement et les bassins de jardin privé sont populaires. Les détenteurs d'écrevisses dans le pays ont été interrogés par questionnaire auto-administré pour recueillir des données sur les caractéristiques principales de ces détenteurs et des informations détaillées sur la reproduction des écrevisses qui sont d'intérêt pour les responsables de la conservation. En plus de mettre des écrevisses dans les bassins de jardin, des comportements illégaux alarmants tels que la libération des écrevisses juvéniles dans la nature, et la capture d'écrevisses indigènes de populations sauvages, ont été enregistrés. Par conséquent, mettre l'accent sur l'éducation du public pour mieux faire connaître les éventuelles conséquences indésirables de propager des écrevisses et l'introduction d'une obligation pour les détaillants et les grossistes d'informer les clients sur la dangerosité des espèces d'écrevisses non indigènes sont recommandés.

(1) Department of Zoology and Fisheries, Faculty of Agrobiology, Food and Natural Resources, Czech University of Life Sciences Prague, Kamýcká 129, 16521 Praha 6 - Suchdol, Czech Republic

* Corresponding author: patoka@af.czu.cz 


\section{INTRODUCTION}

The keeping of aquatic animals in home aquariums and garden ponds is globally very popular hobby with many followers (Turkmen and Karadal, 2012). However, it is also one of the main pathways for introduction of alien species on new localities (Holdich et al., 2009; Kopecký et al., 2013). Crayfish became in last decades popular pet species that is often kept in indoor aquaria but also stocked in the private garden ponds (Peay, 2009). With regard to crayfish biology, it is obvious that there is a high probability of their escapes from gardens into the wild. This is particularly important for non-indigenous crayfish species (NICS), which can dramatically harm the ecosystems and many of the native species (Peay, 2009). Besides to direct competition, very dangerous for indigenous crayfish species (ICS) in Europe is crayfish plague caused by the fungus Aphanomyces astaci, which is carried by usually resistant North American species of crayfish (Edgerton et al., 2004).

Following NICS which most probably originated from aquarium release have been recorded in EU countries: e.g. Procambarus fallax f. virginalis in Germany (Chucholl and Pfeiffer, 2010) and Italy (Nonnis Marzano et al., 2009), Netherlands (Soes and Koese, 2010), Slovakia (Janský and Mutkovič, 2010) and surprisingly in Sweden (Bohman et al., 2013), Cherax destructor in Italy (Scalici et al., 2009), and Cherax quadricarinatus in Slovenia (Jaklic and Vrezec, 2011). The introduction pathway of successful invader Orconectes immunis into Europe is unknown and pet trade is one of possible eventualities (Chucholl, 2012). Certain naturalized populations of commercially important Procambarus clarkii were most probably introduced in the same pathway (Chucholl, 2013). Moreover Chucholl (2013) warns, that NICS as Pacifastacus leniusculus, Orconectes limosus, O. cf. virilis, and Cambarellus patzcuarensis are advertised for garden pond stocking in Germany; and Stloukal (2009) reported about stocks of $P$. fallax f. virginalis which were found in garden ponds in Slovakia. The information about NICS in terms of their occurrence, abundance and introduction pathways is very important for the correct management and conservation of ICS (Souty-Grosset and Reynolds, 2009).

The Czech Republic is considered as one of the leading European countries with ornamental crayfish trade (Patoka et al., 2014) and small ponds with live crayfish are popular among crayfish keepers in the Central Europe (Peay, 2009). The local ICS in the Czech Republic are under the threat of already introduced NICS (Orconectes limosus and Pacifastacus leniusculus) and the future establishment of newly introduced NICS cannot be excluded under mentioned conditions.

Although there already exists risk assessment for ornamental NICS in the Czech Republic (Patoka et al., 2014) and the garden ponds are considered as important pathway for introduction, more detailed data could help to elucidate main causes of the NICS potential spreading and identified behavior and habits of the crayfish keepers for further consideration in legislation, public education and environmental management.

\section{MATERIALS AND METHODS}

Ornamental crayfish keepers living in the Czech Republic were interviewed with a questionnaire. A self-administered two-page questionnaire containing 14 close-ended questions was designed to collect data on socio-demographic characteristics of keepers and details of crayfish keeping and breeding. The questionnaire distribution was performed from February to August 2013. The goal of the questionnaire was to collect as many responses from crayfish keepers as possible. Therefore, questionnaires were distributed among respondents in pet exhibitions, in pet shops, at the Czech Aquarium and Terrarium Association, at the Czech University of Life Sciences Prague and they were inserted at the internet forums focused on keeping of ornamental animals. The respondents were guided to fill the questionnaire on the web or on paper. The anonymity of the data was obviously guaranteed. In according to experience of Arlinghaus and Mehner (2003), the publication of our results in specialized aquarium breeding magazine was offered to reduce skepticisms and encourage participation of respondents. A total of 124 crayfish keepers from all regions of the Czech Republic 


\section{Where do you obtain your crayfish?}

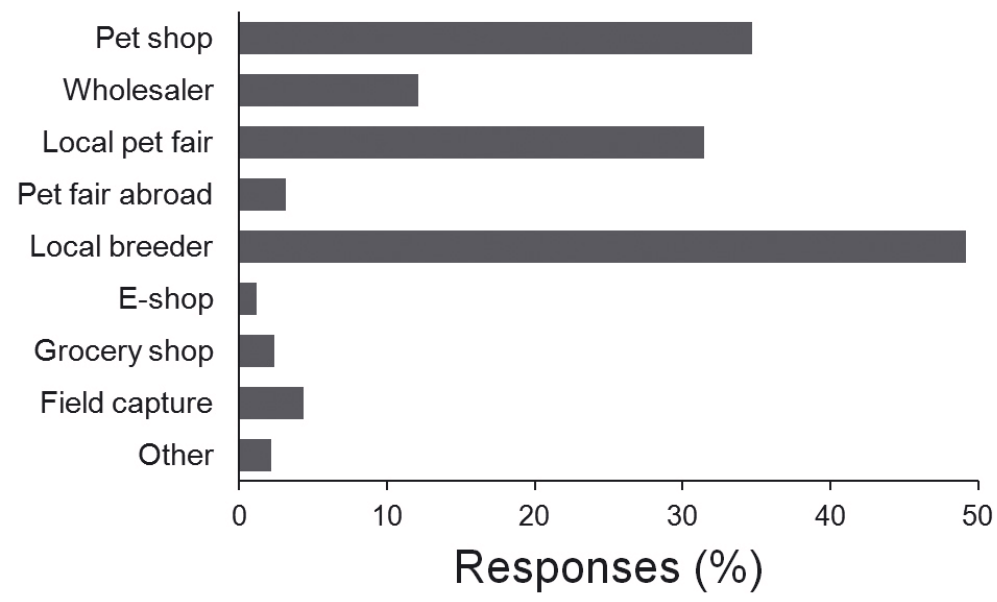

Figure 1

Origin of crayfish which are kept as ornamental - given in \% ( $N=124)$. Note: Since the multiple-answer type of this question, the total percentage of responses is higher than 100.

responded. The gathered data set would be insufficient for statistical analysis; hence the percentage approach was implemented according to Arlinghaus and Mehner (2003). Percentage values were approximated on one decimal position.

\section{RESULTS}

Based on gathered data, most responses characterize the keeper of ornamental crayfish as male $(56.5 \%, N=70)$ which lives in capital city Prague $(21.0 \%, N=26)$, he is aged $21-30$ years old $(40.3 \%, N=50)$ and high-school educated $(66.1 \%, N=82)$. Vast majority of crayfish keepers responded, that their annual costs for crayfish keeping are less than 200 EUR (85.5\%, $N=106)$. Most respondents $(75.0 \%, N=93)$ obtain information about crayfish keeping and breeding on internet. Altogether $3.8 \%(N=11)$ of respondents feed crayfish with fresh or frozen shrimps. Most frequent crayfish in keeping is Procambarus fallax $\mathrm{f}$. virginalis (36.3\%, $N=45)$, Cambarellus patzcuarensis (33.9\%, $N=42)$ and Procambarus clarkii $(20.2 \%$, $N=25)$. Other species are kept in less than $10 \%$ of cases: Astacus astacus, $A$. leptodactylus, Cambarellus diminutus, Cam. montezumae, Cam. puer, Cam. texanus, Cherax albertisii, Cher. boesemani, Cher. cainii, Cher. destructor, Cher. holthuisi, Cher. monticola, Cher. quadricarinatus, Cher. peknyi, Cher. preisii, Cherax sp., Orconectes limosus, Pacifastacus leniusculus, Procambarus alleni, P. cubensis. Altogether $12.1 \%(N=15)$ of respondents were unable to determine kept species. Three respondents keep in captivity ICS protected by law: Astacus astacus in two cases, Astacus leptodactylus in one case. Many respondents have been keepers of ornamental crayfish less than period of one year $(41.1 \%, N=51)$ or from one to five years $(38.7 \%, N=48)$. Just over half of kept crayfish originated from private breeders $(49.2 \%, N=61)$ and from pet shops $(34.7 \%, N=43)$. Only $2.4 \%(N=3)$ of keepers bought crayfish marketed for consumption purposes. Surprisingly $5.4 \%(N=10)$ of respondents admitted illegal field capture of crayfish (Figure 1). The crayfish are mostly kept in low quantities: $2-5$ individuals in $40.3 \%(N=50)$ and just only one individual in $29.8 \%(N=37)$. More than 10 individuals are kept in $21.0 \%(N=26)$. Vast majority of respondents keep the crayfish in indoor aquarium $(91.9 \%, N=114)$, but $8.1 \%(N=10)$ released them into the garden ponds (Figure 2). When crayfish reproduce, most of breeders keep them for rearing or advertise them for sale or give them away to friends. But $2.1 \%(N=4)$ release juveniles into the wild and $1.5 \%(N=3)$ flush them down the toilet (Figure 3). Just $4.0 \%(N=5)$ of respondents keep 


\section{Under which conditions are you currently keeping or have you kept crayfish?}

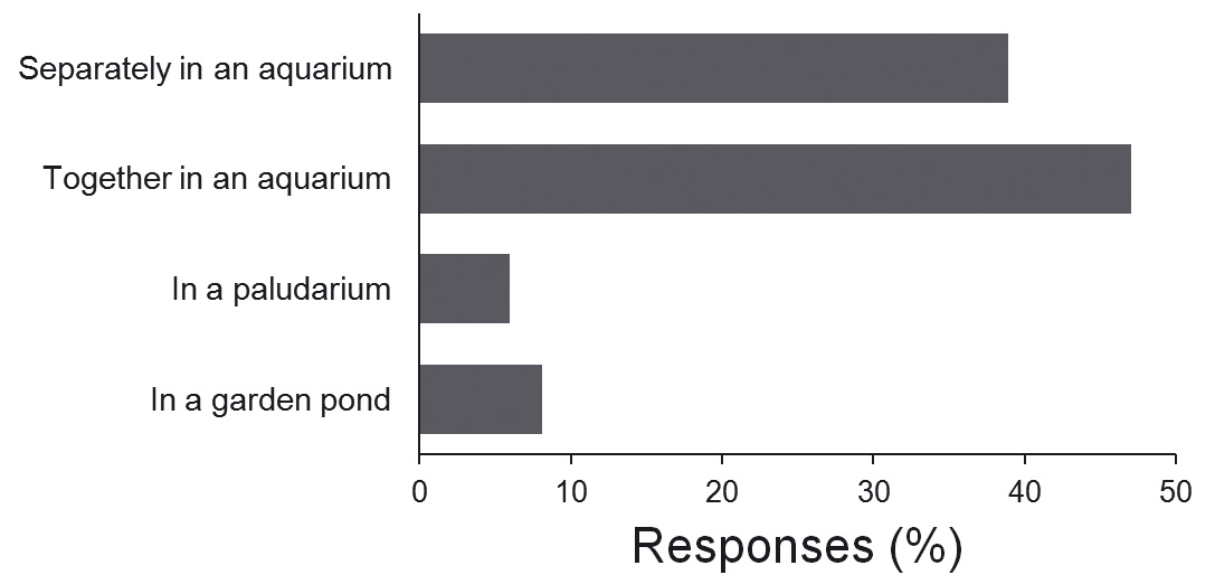

\section{Figure 2}

Types of environment where ornamental crayfish are kept - given in \% $(N=124)$. First three options together show keeping in indoor tanks.

\section{If your crayfish reproduce, what do you do with the offspring?}

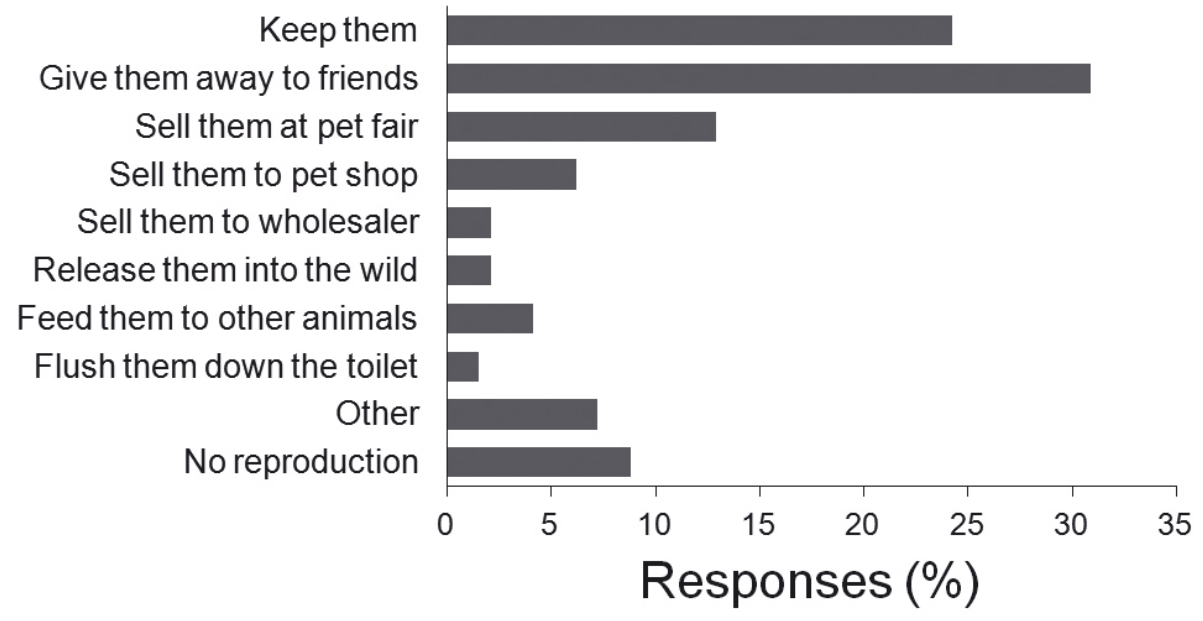

Figure 3

Handling with offspring of kept crayfish - given in \% ( $N=124)$.

in captivity crayfish only and the others prefer to keep more animals as pet or ornamental, especially fish $(76.6 \%, N=95)$.

\section{DISCUSSION}

Most common ornamental crayfish is Procambarus fallax $\mathrm{f}$. virginalis which is inexpensive, easily bred, with low intraspecies aggressiveness and thus very popular (Chucholl, 2013; Patoka et al., 2014). Popularity of the Cambarellus patzcuarensis which is the second most preferred species for keeping is related with its orange coloration and small body length and thus it has low requirements for space. In addition to previous study (Patoka et al., 2014), 
we recorded one new species Cambarellus montezumae kept in the Czech Republic. This crayfish is very rare in crayfish keeping and it most probably originates from private import from Germany, where this crayfish was frequently available in online pet shops (Chucholl, 2013).

People who like wildlife also often prefer to keep animals in facilities close to natural conditions as it is in case of garden ponds (Peay, 2009). In many EU countries, stocking of NICS in ponds is banned without exception from the law, but small private garden ponds are not controlled in any way (Peay, 2009). Although vast majority of crayfish keepers rear ornamental crayfish strictly in home aquarium, part of them commonly release crayfish into garden ponds at least for the summer period. These irresponsible activities are considerably dangerous for ICS and other native biota, because there is non-negligible probability that NICS escape from ponds spontaneously or during a flood (Peay, 2009).

Moreover part of keepers introduces offspring of ornamental crayfish directly into the wild or flush them down the toilet. These illegal activities can participate on spreading of NICS. Although, crayfish most probably do not survive passage through the toilet downspouts, it can be one of the pathways of crayfish plague transmission.

Capturing and trapping of ICS in the wild is also forbidden in many EU countries (including the Czech Republic) by the law number 92/43/EEC. ICS are advertised as ornamental very rarely in the Czech Republic (Patoka et al., 2014), anyway we identified that two ICS are sporadically kept by crayfish keepers. Therefore it is evident, that these species are occasionally illegally taken away from wild populations.

It appears from above mentioned that garden pond stocking of ornamental crayfish and related activities are in many cases undesirable and hence we recommend intensive public education to increase general awareness of possible unwanted consequences of NICS escapes from garden ponds or even their release into the wild. The retailers and wholesalers should be obliged to inform customers about hazardousness of NICS and provide the information with the advertised crayfish species for sale.

\section{ACKNOWLEDGEMENTS}

We are thankful to many anonymous respondents for their willingness and participation. Especially thank to Martina Jarošová (student at Czech University of Life Sciences Prague) for help with data collection. This paper was supported by the grant of Technology Agency of the Czech Republic No. TD010045 and CIGA No. 20132016.

\section{REFERENCES}

Arlinghaus R. and Mehner T., 2003. Socio-economic characterisation of specialised common carp (Cyprinus carpio L.) anglers in Germany, and implications for inland fisheries management and eutrophication control. Fish. Res., 61, 19-33.

Bohman P., Edsman L., Martin P. and Scholtz G., 2013. The first Marmorkrebs (Decapoda: Astacida: Cambaridae) in Scandinavia. Bioinvasions Rec., 2, 227-232.

Edgerton B.F., Henttonen P., Jussila J., Mannonen A., Paasonen P., Taugbøl T., Edsman L. and Souty-Grosset C., 2004. Understanding the causes of disease in European freshwater crayfish. Conserv. Biol., 18, 1466-1474.

Chucholl C., 2012. Understanding invasion success: life-history traits and feeding habits of the alien crayfish Orconectes immunis (Decapoda, Astacida, Cambaridae). Knowl. Managt. Aquatic Ecosyst., 404, 04.

Chucholl C., 2013. Invaders for sale: trade and determinants of introduction of ornamental freshwater crayfish. Biol. Invasions, 15, 125-141.

Chucholl C. and Pfeiffer M., 2010. First evidence for an established Marmorkrebs (Decapoda, Astacida, Cambaridae) population in Southwestern Germany, in syntopic occurrence with Orconectes limosus (Rafinesque, 1817). Aquat. Invasions, 5, 405-412. 
Holdich D.M., Reynolds J., Souty-Grosset C. and Sibley P., 2009. A review of the ever increasing threat to European crayfish from non-indigenous crayfish species.Knowl. Managt. Aquatic Ecosyst., 394-395, 11.

Jaklic M. and Vrezec A., 2011. The first tropical alien crayfish species in European waters: the redclaw Cherax quadricarinatus (Von Martens, 1868) (Decapoda, Parastacidae). Crustaceana, 84, 651-665.

Janský V. and Mutkovič A., 2010. Rak Procambarus sp.(Crustacea: Decapoda: Cambaridae) - Prvŷ Nález na Slovensku. Zbornik Slovenského Národneho Múzea (Acta rerum naturalium Musei Nationalis Slovaci Bratislava), 56, 64-67.

Kopecký O., Kalous L. and Patoka J., 2013. Establishment risk from pet-trade freshwater turtles in the European Union. Knowl. Managt. Aquatic Ecosyst., 410, 02.

Nonnis Marzano F., Scalici M., Chiesa S., Gherardi F., Piccinini A. and Gibertini G., 2009. The first record of the marbled crayfish adds further threats to fresh waters in Italy. Aquat. Invasions, 4, 401-404.

Patoka J., Kalous L. and Kopecký O., 2014. Risk assessment of the crayfish pet trade based on data from the Czech Republic. Biol. Invasions, DOI: 10.1007/s10530-014-0682-5.

Peay S., 2009. Invasive non-indigenous crayfish species in Europe: recommendations on managing them Knowl. Managt. Aquatic Ecosyst., 394-395, 03.

Scalici M., Chiesa S., Gherardi F., Ruffini M., Gibertini G. and Nonnis Marzano F., 2009. The new threat to Italian inland waters from the alien crayfish "gang": the Australian Cherax destructor Clark, 1936. Hydrobiologia, 632, 341-345.

Soes D. and Koese B., 2010. Invasive crayfish in the Netherlands: a preliminary risk analysis, EISNederland and Bureau Waardenburg, Leiden, $69 \mathrm{p}$.

Souty-Grosset C. and Reynolds J., 2009. Current ideas on methodological approaches in European crayfish conservation and restocking procedures. Knowl. Managt. Aquatic Ecosyst., 394-395, 01.

Stloukal E., 2009. Recent distribution of nonindigenous crayfish species in Slovakia. Folia Faunistica Slovaca, 14, 119-122.

Turkmen G. and Karadal O., 2012. The survey of the imported freshwater decapod species via the ornamental aquarium trade in Turkey. J. Anim. Vet. Adv., 11, 2824-2827. 


\section{QUESTIONNAIRE}

1. Please check the region of your residence:

Praha

Jihočeský

Jihomoravský

Karlovarský

Královéhradecký

Liberecký

Moravskoslezský

Olomoucký

Pardubický

Plzeňský

Středočeský

Ústecký

Vysočina

Zlínský

2. Please check your age group:

10 to 20

21 to 30

31 to 40

41 to 50

51 to 60

more than 60

3. Please check appropriate sex:

male

female

4. Please check your highest completed education:

elementary

secondary school

higher education

5. Specify which species of crayfish you currently keep or have kept:

Rak mramorový (Procambarus fallax f. virginalis)

Rak červený (Procambarus clarkii)

Procambarus alleni

Trpasličí mexický rak (Cambarellus patzcuarensis - CPO)

Cherax destructor

Cherax quadricarinatus

Cherax peknyi (C. papuanus, C. misolicus, C. sp. Zebra)

Cherax holthuisi (Apricot, Orange Coral)

Other (please specify)

6. How long have you been involved with the keeping of ornamental crayfish?

less than 1 year

$1-5$ years

$6-10$ years

more than 10 years

7. What is your preferred source of information with respect to ornamental crayfish?

internet

printed materials (publications)

breeders

pet exhibitions

hobby organisations

acquaintances

information not available

other 
8. Where do you obtain your crayfish?

pet shops

wholesalers

local pet fair

pet fair abroad

breeders

e-shops

grocery shops

field capture

other

9. Please check the quantity of crayfish you are currently keeping or have kept:

1 individual

2 to 5 individuals

6 to 10 individuals

more than 10 individuals

10. Under which conditions are you currently keeping or have you kept ornamental crayfish? separately in an aquarium

together in an aquarium

in a paludarium

in a garden pond

other

11. If your crayfish reproduce, what do you do with the offspring?

keep them

give them away to friends

sell them at pet fair

sell them to pet shop

sell them to wholesaler

release them into the wild

feed them to other animals

flush them down the toilet

other

no reproduction

12. What are your annual expenses associated with keeping crayfish?

less than 200 EUR

200 to 400 EUR

more than 400 EUR

13. What do you feed your crayfish?

vegetables (fresh, dried, frozen)

fish (fresh, dried, frozen)

insect larvae, worms or snails (live, frozen)

shrimp meat (fresh, frozen)

artificial feed for aquarium fish

artificial feed for aquarium crustaceans

other

14. Are you currently keeping aquarium or terrarium animals other than crayfish?

fishes

crustaceans (e.g. shrimps, crabs, hermit crabs)

molluscs (e.g. snails)

amphibians (e.g. frogs, newts)

reptiles (snakes, lizards, turtles, crocodiles)

insects (e.g. beetles, mantises, leaf insects)

spiders or scorpions

other

nothing 